VERTAISARVIOITU

KOLLEGIALT GRANSKAD

PEER-REVIEWED

www.tsv.fi/tunnus

\title{
SELKO SUOMESSA - \\ SELKOKIELEN KEHITYS JA SOVELLUKSIA
}

\section{Eliisa Uotila, Helsingin yliopisto}

Katsaus käy läpi suomenkielisen selkokielen kehityksen vaiheita Suomessa 1980-luvulta nykypäivään. Katsauksessa kerrotaan käytännön toimista selkokielen kehittämiseksi sekä tutkimuksesta, jota selkokielestä on tehty. Selkokieltä alettiin kehittää Suomessa 1980-luvulla. Äänekkäimmin selkokieltä vaativat kehitysvammahuollon toimijat, vaikkakin selkokielen hyöty monille muillekin ihmisryhmille tunnistettiin. Selkokieltä on kehitetty käytännön työn ja kohderyhmätestauksen avulla. Teoreettisempaa tukea on haettu esimerkiksi erityispedagogiikasta sekä viestinnän- ja muistintutkimuksen aloilta. Selkokielestä kielimuotona on vielä melko vähän tutkimusta, mutta tilanne on muuttumassa selkokielen tunnettuuden ja käytön lisääntyessä. Selkokielen määritelmän mukaan selkokieli on tekstin, sanaston ja rakenteiden tasoilla helpompaa kuin yleiskieli. Selkokieleen liittyy olennaisesti myös visuaalisuus, esimerkiksi kuvituksen ja taiton ohjeistus. Selkokieltä on pitkään sovellettu myös vuorovaikutukseen. Selkokielen tarve voi johtua pysyvistä neurobiologisista syistä (esim. kehitysvamma, autismin kirjo), heikentyneistä kielellisistä taidoista (esim. muistisairaudet ja aivoverenkierron häiriöt) tai todennäköisesti kehittyvistä kielellistä taidoista (esim. uuden kielen opiskelu). Selkokielen tarkoitus on estää kielellistä syrjäytymistä sekä mahdollistaa tasa-arvoisempaa ja itsenäisempää elämää henkilöille, joille yleiskieli on liian vaikeaa. Selkokielellä on julkaistu pitkään esimerkiksi kirjoja ja lehtiä sekä tiedotusmateriaaleja ( $\mathrm{mm}$. äänestäminen, Kelan etuudet).

Avainsanat: saavutettavuus, selkokieli, selkokirjallisuus, selkosovellukset

Katsaus kokoaa yhteen selkokielestä kerättyä tietoa ja nostaa tärkeitä virstanpylväitä esiin. Se keskittyy suomenkielisen selkokielen kehitykseen eikä siinä ole siksi käsitelty ruotsinkielistä selkokieltä (lättläst) Suomessa (ks. LL. Center, 2019). Lisäksi katsauksessa painottuu selkokielen kirjoitettu muoto muiden selkoilmaisun muotojen, kuten selkojulkaisun taiton, selkokuvan ja selkokielisen vuorovaikutuksen, jäädessä sivujuonteeksi.

Katsaus alkaa nykytilanteesta ja määrittelyistä. Luvussa kaksi palataan selkokielen alkuvaiheisiin ja kartoitetaan polkua kohti vallitsevaa käsitystä selkokielestä. Selkokieli on ollut tutkimuskohteena harvakseltaan, eikä sitä ole kovin systemaattisesti Suomessa tai maailmalla vielä tutkittu. Kritiikistä ja tutkimuksesta esitellään sellaisia, jotka ovat merkittävällä tavalla vaikuttaneet selkokielen kehitykseen. Lisäksi katsauksen lopuksi luvussa kolme esitellään selkokielen sovelluksia.

Kirjoittajan yhteystiedot: Eliisa Uotila, eliisa.uotila@helsinki.fi 


\section{SELKOKIELEN NYKYTILANNE}

Läpi historiansa selkokieltä on perusteltu tasa-arvolla ja ihmisoikeuksilla, esimerkiksi oikeudella tietoon ja mahdollisuudella osallistua yhteiskunnan toimintaan paremmin (mm. Virtanen, 1986, s. 9-10; IFLA, 2010, s. 3). Selkokieli on kuitenkin saanut laajemman yhteyden ja paikan saavutettavuuskeskustelussa vasta 2000-luvulla edustaen kielellistä ja tiedollista eli kognitiivista saavutettavuutta (Leskelä, 2019a, s. 48-50). Selkokielen tehtävä on alusta asti ollut selvä: estää kielellistä syrjäytymistä.

Suomessa selkokieltä kehittää Selkokeskus (Selkokeskus, 2019a). Se myös tuottaa materiaaleja selkosuomeksi, kouluttaa selkokielen käytössä ja tekee vaikuttamistyötä selkokielen aseman parantamiseksi. Vuonna 2000 perustettu Selkokeskus saa rahoituksensa Sosiaali- ja terveysjärjestöjen avustuskeskukselta (STEA), joka toimii Sosiaali- ja terveysministeriön yhteydessä ja joka jakaa Veikkauksen varoja kansalaisjärjestöille. Vaikuttamistyötä selkokielen puolesta tekee Selkokeskuksen rinnalla Selkokielen neuvottelukunta, jossa on jäseninä esimerkiksi viranomaisia, oppilaitoksia ja järjestöjä. Se laatii viiden vuoden välein toimenpideohjelman (Selkokeskus, 2019b) selkokielen käytön ja aseman parantamiseksi sekä ottaa yhdessä Selkokeskuksen kanssa kantaa selkokielen ja sen käyttäjäryhmien kannalta olennaisiin yhteiskunnallisiin ja ajankohtaisiin asioihin (Leskelä, 2019a, s. 264-265).

\subsection{Selkokielen määritelmä ja periaatteet}

Selkokielen määritelmä kuuluu Selkokeskuksen mukaan:

Selkokieli on suomen kielen muoto, joka on mukautettu sisällöltään, sanastoltaan ja rakenteeltaan yleiskieltä luettavammaksi ja ymmärrettävämmäksi. Se on suunnattu ibmisille, joil- la on vaikeuksia lukea tai ymmärtääyleiskieltä. Leskelä (2019a, s. 93)

Määritelmässä selkokieltä katsotaan kolmella eri tavalla: 1) suhteessa Kotimaisten kielten keskuksen määrittelemään yleiskieleen (ks. esim. Tieteen termipankki, 2019), 2) määritellään muutoksia, joita selkokielisyys aiheuttaa ja 3) kiinnitetään tuotettu kieli kohderyhmäajatteluun.

Selkokeskus on kehittänyt pitkään selkokielen mittaria, joka julkaistiin syksyllä 2018. Tekstin, sanaston ja kielen rakenteiden lisäksi mittarin neljäs osio koskee tekstin visuaalista muotoilua (Leskelä, 2019a, s. 195, 210). Nykyisellään mittarissa on yhteensä 106 kriteeriä, joiden tarkoitus on auttaa selkokielen asiantuntijoita arvioimaan tekstin selkokielisyyttä (Leskelä, 2019a, s.112-115; Leskelä, 2019b).

Selkokielen yleiset periaatteet on jaettu kielen kannalta kolmeen eri tasoon: tekstin, sanaston ja rakenteiden tasoon (Leskelä, 2019a, s. 112). Seuraavaksi käydään läpi hyvin lyhyesti, miten periaatteita on sovellettu selkokirjoittajan ohjeiksi:

Tekstin tasolla kirjoittaja määrittelee tekstinsä lukijaa ja miettii esimerkiksi aihetta, esittämisjärjestystä, näkökulmaa ja informaation määrää hänen kannaltaan sekä selventää tekstissä syy-seuraussuhteita ja huolehtii tekstin koheesiosta (Leskelä, 2019a, s. 116-120).

Sanastotasolla kirjoittaja välttää pitkiä sanoja ja varsinkin niiden vaikeita taivutusmuotoja sekä selittää vaikeat, abstraktit sanat ja käsitteet tekstiyhteydessä. Lisäksi hän valitsee abstraktiotasoltaan mahdollisimman konkreettisia ja lukijalle tuttuja sanoja, havainnollistaa abstrakteja käsitteitä konkreettisin esimerkein ja on varovainen kielikuvien ja sanontojen käytössä (Leskelä, 2019a, s. 128-139).

Kielen rakenteiden tasolla kirjoittaja suosii lyhyitä lauseita ja virkkeitä, tavallisia sijamuotoja sekä finiittiverbejä passiivin sijaan. 
Lisäksi hän esimerkiksi välttää pitkiä määriteketjuja ja lauseenvastikkeita (Leskelä, 2019a, s. 141-175).

Näiden yleisten ohjeiden lisäksi Leskelä ja Kulkki-Nieminen (2015) ovat paneutuneet tekstilajikohtaisiin ohjeisiin käyden läpi mediatekstien sekä informoivien ja kaunokirjallisten tekstien erityispiirteitä selkokielen kontekstissa (kaunokirjallisuuden mukauttamisesta ks. myös Sainio, 2006).

Selkokeskus on viime vuosina kehitellyt yllämainittujen yleisten periaatteiden rinnalla ajatusta eri tasoisista selkokielistä ja kehittänyt näille kolmelle eri tasolle myös erikseen kriteerejä ja ohjeita. Tasoja kutsutaan tällä hetkellä nimillä perusselkokieli, tätä helpompi helppo selkokieli sekä perusselkokieltä vaikeampi vaativa selkokieli, mutta jako sekä nimitykset ovat vielä alustavia ja saattavat muuttua kehitystyön kuluessa. Selkokeskuksen tarkoituksena on osin ollut sanoittaa vallitsevaa tilannetta, jossa selkotunnuksen saaneissa materiaaleissa on kielellisesti vaihtelua, sekä parantaa selkokirjoittajien mahdollisuuksia vastata kulloisenkin lukijajoukkonsa erityistarpeisiin (Leskelä, 2019a, s. 160-162; Leskelä, 2019b).

Selkokielen periaatteisiin on alusta asti kuulunut myös (painetun) julkaisun visuaalinen puoli eli esimerkiksi taitto ja kuvitus, vaikka varsinaisessa määritelmässä näitä seikkoja ei ole huomioitu (esim. Rajala \& Virtanen, 1986, s. 26-29). Selkojulkaisuissa esimerkiksi teksti on tasattu vain vasempaan reunaan (liehu) ja rivit ovat normaalia lyhyempiä lukemisprosessin helpottamiseksi (Leskelä, 2019a, s.187-188). Selkotaitolla pyritään auttamaan lukijaa esimerkiksi vähentämällä työmuistin kuormaa, helpottamalla tekstin kokonaisrakenteen ymmärtämistä ja tekemällä tekstistä taiton avulla mielenkiintoa herättelevän (Leskelä, 2019a, s. 177-179).

Oma lukunsa on selkokielen linkittyminen internetin ja verkkopalvelujen saavutettavuu- teen. Selkokeskus on linjannut, että verkkoteksteissä on otettava huomioon kielen kannalta kaikki kirjoitetun selkokielen ohjeet ja periaatteet. Selkotaiton näkyvin piirre, lyhyemmät rivit, on mahdollista osin toteuttaa palstakokoa pienentämällä, mutta tarkka rivinvaihdon määrittäminen on mahdotonta selainten erojen ja erikokoisten näyttölaitteiden takia (Virtanen, 2014 [2009], s. 166168). Verkkosivuilla leipätekstiin liittyvien asioiden lisäksi on otettava myös huomioon muu ymmärrettävyys ja käytettävyys (esim. navigaatiorakenne, sivustolla liikkuminen, hakutoiminto ja virheilmoitukset) (Leskelä, 2019a, 65-70; ks. myös Papunet, 2019).

EU-tasolta tuleva ns. saavutettavuusdirektiivi ((EU) 2016/2102) on edellyttänyt yhteiskunnallista keskustelua ja toimenpiteitä julkishallinnon tasolta. Direktiivi ottaa kantaa varsinkin julkisen sektorin verkkosivujen ja -palveluiden saavutettavuuteen. Myös kansallisessa lainsäädännössä (hallintolaki, yhdenvertaisuuslaki) olevat kirjaukset saavutettavuuteen liittyen sekä Suomen vuonna 2016 allekirjoittama ja ratifioima YK:n yleissopimus vammaisten ihmisten oikeuksista (YK-liitto, 2015) korostavat aiheen painoarvoa. Selkokeskus on ollut mukana tässä ajankohtaisessa keskustelussa ja pyrkinyt varmistamaan, että kielellinen ja kognitiivinen saavutettavuus otettaisiin riittävästi huomioon (Leskelä, 2019a, 68-70).

Selkokieltä on myös jo pitkään sovellettu puhuttuun kieleen. Osa selkokielen periaatteista sopii sellaisinaan vuorovaikutuksen ohjeiksi, mutta niiden lisäksi on luotu ohjeistusta nimenomaan vuorovaikutustilanteisiin kattaen myös ei-kielellisiä osa-alueita kuten kohtaaminen ja läsnäolo. Huomiota on kiinnitetty myös puheen prosodisiin piirteisiin (Leskelä, 2012a). Leskelä ja Lindholm (2012a) puhuvat tässä yhteydessä kielellisestä epäsymmetriasta, jossa siis vähintään yhdellä osallistujalla on merkittäviä kielellisiä vaikeuksia. 


\subsection{Selkokielen kohderybmät}

Selkokielen kohderyhmät ovat pysyneet melko samoina, vaikka esimerkiksi diagnoosit ja niidet nimet ovat voineet vuosikymmenten kuluessa hieman muuttua. Lisäksi huomionarvoisia ovat eri kohderyhmien määrissä tapahtuneet muutokset, ja tämän myötä tarvearvioissa ja myös selkokielen sovellusten suuntaamisessa tapahtuneet muutokset.

Leskelä ja Lindholm (2012b) jakavat selkokielen kohderyhmiä kielitaidon muutoksen mukaan:

1. pysyvät ja synnynnäiset neurobiologisista syistä kielellisesti poikkeavat taidot (esim. kehitysvammaiset tai autismin kirjon henkilöt, kielelliset erityisvaikeudet)

2. elinaikana vamman tai sairauden vuoksi heikentyneet kielelliset taidot (esim. muistisairaat tai afaattiset henkilöt)

3. todennäköisesti kehittyvät kielelliset taidot eli kielellisen tuen tarve on väliaikaista ja lisäksi käytössä on jokin muu toimiva kieli tai kommunikaatiomenetelmä (kielenoppijat, viittomakieliset, vähemmistökielten puhujat)

Jako yllä on karkea, mutta havainnollistaa hyvin eri ryhmien suhdetta selkokieleen ja kertoo myös selkokielen tarvitsijoiden suuresta kirjosta. Selkokielen tarvitsijaryhmille eri asiat ovat vaikeita kielenkäytössä. He hyötyvät kuitenkin selkokielestä joka tapauksessa verrattuna yleiskieliseen vastineeseen, vaikka selkokieltä ei olisi erityisesti suunnattu juuri ko. kohderyhmälle (Leskelä, 2019a, s. 103-104; Leskelä \& Kulkki-Nieminen, 2015, s. 22-32).

Myös esimerkiksi kansainvälinen kirjastojen kattojärjestö IFLA (2010) jakaa selkokielen tarpeen kahtia: pysyvään ja väliaikaiseen selkokielen tarpeeseen. Inclusion Europen (2009) ohjeistuksessa kehitysvammaiset henkilöt ovat selkokielen pääkohde, mutta tässäkin ohjeistuksessa mainitaan selkokielen soveltuvuus myös muille ryhmille.

Edellä mainittujen pääryhmien lisäksi selkokieli voi olla hyödyksi esimerkiksi mielenterveys- ja päihdekuntoutujille sekä syrjäytyneille. Nykypäivän monimutkaisessa tietoyhteiskunnassa on hyvä muistaa myös ns. laaja yleisö ja toisaalta yksilöidenkin hetkelliset tarpeet (Leskelä, 2019a, s. 102-103).

Syyt selkokielen tarpeelle eivät ole pääpiirteissään kovin paljon muuttuneet, mutta määrällinen arvio selkokielen tarpeesta Suomessa on kasvanut vuosikymmenten aikana selvästi. Selkokeskus on selvittänyt selkokielen tarvetta esimerkiksi kartoittamalla eri etujärjestöjen arvioita oman kohderyhmänsä edustajien määrästä Suomessa ja tekemällä vertailuja kansainvälisiin tietoihin. Lisäksi on tarkasteltu erityisopetusta saavien oppilaiden osuuksia sekä myöhemmin tutustuttu myös erilaisiin lukutaitotutkimuksiin.

Vuoden 2019 tarvearvion (Selkokeskus, 2019c, s. 20) mukaan selkokielen kohderyhmiin kuuluu arviolta 650 000-750 000 henkilöä, mikä on noin 100000 enemmän kuin edellisessä tarvearviossa vuodelta 2014. Tarvearvio perustuu Tilastokeskuksen ja THL:n tilastotietoihin, lukutaitotutkimuksiin (PISA, PIAAC) ja eri kansalaisjärjestöjen kokoamiin lukuihin, jotka ovat olleet saatavilla vuoden 2018 lopulla (Selkokeskus, 2019c, s. 5). Tarvearviossa esitetään seuraavia syitä selkokielen tarpeen kasvulle:

- Maahanmuuttajien määrä on kasvanut. Suomessa asuvien vieraskielisten ihmisten määrä on kasvanut vuodesta 2014 noin 100000 ihmisellä.

- Yli 65-vuotiaita ihmisiä on yhä enemmän. Väestön ikääntyessä muistisairaudet ja muut oppimisen ja ymmärtämisen ongelmat yleistyvät. 
- Nuorten lukutaito on heikentynyt viime vuosina. Esimerkiksi PISA 2015 -tutkimuksen mukaan noin $11 \%$ suomalaisnuorista lukee heikosti. Myös tehostetun ja erityisen tuen tarve peruskouluissa on kasvanut selvästi.

Selkokeskus (2019c, s. 20)

Selkokeskus on aina pyrkinyt maltilliseen arvioon ja korostaa, että mainituissa kohderyhmissä selkokielen tarve koskee vain osaa joukosta ja osa selkokielen tarvitsijoista kuuluu samanaikaisesti moneen kohderyhmään. Lisäksi selkokielen tarve on myös tilannesidonnaista (Selkokeskus, 2019c, s. 5).

Lukutaitotutkimukset (esimerkiksi PISA, PIAAC) antavat suuntaa koko Suomen lukutaidon kehittymisestä ja suunnasta. PISA-tutkimusten laskeva trendi on nostanut nuorison lukutaidon median ja kansakunnan tietoisuuteen. Lisäksi huomiota on saanut poikien ja tyttöjen ero tuloksissa (Lukukeskus, 2017, s. 1-4). Aikuisten lukutaitotutkimukset (PIAAC) ovat selkokielen kannalta mielenkiintoisia, mutta ne loppuvat 65 ikävuoteen. Näin ollen vanhusväestön lukutaidon taso ja selkokielen tarve jäävät tässä kokonaan kartoittamatta (Virtanen, 2014 [2009], s.34-35). Malin (2006) on analysoinut siihenastisia lukutaitotutkimuksia ja muistuttaa heikon lukutaidon ja syrjäytymisen korrelaatiosta. Osalla aikuisväestöstä lukutaidon puutteet ovat niin suuria, että ne voivat heikentää oppimista, työntekoa sekä rajoittaa arkielämää ja harrastuksia.

\section{SELKOKIELEN KEHITYS JA TUTKIMUS}

Rajalan ja Virtasen (1986, s. 9-11) mukaan kiinnostus selkokieltä kohtaan kasvoi yhteiskunnallisen ja teknisen kehityksen myötä. Huoli koski erityisesti ihmisryhmää, johon tuohon aikaan viitattiin käsitteellä kielellisesti rajoittuneet. Rajalan ja Virtasen mukaan kielellisten seikkojen takia heidän mahdollisuutensa seurata yhteiskunnan toimintaa tai osallistua siihen olivat selvästi huonommat kuin muilla. Vaatimukset integraatiosta, tasa-arvosta ja mahdollisuudesta käyttää yleisiä palveluita edellyttivät toimenpiteitä yhteiskunnalta. Vehmaan (2005, s. 17, 122) mukaan ajassa näkyi vammaisliikkeen esittämä, yksilön vammaan kiinnittyneen lääketieteellisen mallin kritiikki. Vaihtoehtona tälle nähtiin vammaisuuden sosiaalikonstruktionistinen näkökulma, jossa vammaisuus on kulttuurisesti luotu konstruktio ja aiheutuu yhteiskunnan kyvyttömyydestä ottaa huomioon erilaisia toimintarajoitteita.

Selkokielen alkuaikoina ote selkokielen kehittämiseen oli käytännönläheinen ja pääosassa oli tekeminen, esimerkiksi materiaalien julkaiseminen. Palaute kohderyhmiltä oli erittäin tärkeässä roolissa, kun tutkimustietoa itse selkokielestä ei juurikaan ollut (Virtanen, 2006). Taustaa, tukea ja oikeutusta selkotoiminnalle haettiin kuitenkin monilta tieteenaloilta, esimerkiksi viestinnän tutkimuksesta. Selkokielen tieteellinen pohdinta seurasi vasta toiminnan vakiinnuttua, mutta vielä nykyäänkin kontaktilla selkokielen käyttäjiin on tärkeä paikkansa, jotta selkokieli kehittyy ja säilyy aidosti kohderyhmiä palvelevana (Leskelä, 2019a, s. 86-90).

\subsection{Kohti selkokielen periaatteita}

Keskustelu selkokielen tarpeesta alkoi 1980-luvulla Ruotsin esimerkkiä seuraten. Etuliite selko- on vakiintunut suomen kieleen selkokirjallisuuden kautta, sillä Suomen kielen lautakunta ehdotti sitä jo vuonna 1978 suomennokseksi ruotsin lättläst litteratur -termille (Virtanen, 2006). Ruotsissa selkokieltä oli käytetty esimerkiksi kirjallisuudessa jo pitkään. Toimivan tukijärjestelmän turvin naapurimaassamme julkaistiin ensimmäinen selkokirja jo vuonna 1967. Pohjoismaissa on 
ylipäätään kansainvälisesti katsottuna pitkä selkokielen historia (Rajala \& Virtanen, 1986, s. 72-76).

Pohjoismaissa selkokieltä on käytetty laajasti erilaisten ryhmien apuna, mutta osassa Euroopan maita selkokieli on suunnattu tarkemmin tietylle kohderyhmälle, esimerkiksi kehitysvammaisille henkilöille tai kielenoppijoille. Kaikissa maissa suhtautuminen selkokieleen on ollut käytännönläheistä ja kehittämistä on tehty yhdessä kohderyhmien kanssa. Euroopasta ei ole tiedossa juurikaan tutkimustietoa selkokieleen liittyen ennen 2010-luvun tutkimuskentän aktivoitumista Saksassa (Leskelä, 2019a, s. 90-92)

Pohjoismaissa ohjeistuksia kehitettiin aluksi kirjoitettuun selkokieleen, ja kielestä toiseen siirtyivät helpoimmin yleiset ohjeet ja ns. tekstitason ohjeet (esittämisjärjestys, taustatiedon tarve, karsiminen) (Rajala ja Virtanen, 1986, s. 31-33). Kielikohtaisia ohjeita mietittäessä Selkokeskus haki tukea esimerkiksi lapsen kielenkehityksen tutkimuksesta, lukemaan oppimisen eri vaiheista ja viestinnän tutkimuksesta, esimerkiksi luettavuuskaavoista (Leskelä, 2019a, s. 87-89; Rajala \& Virtanen, 1986, s. 13-18, 22-25).

Selkokielen määritelmä on pysynyt melko samana vuosikymmenten aikana, mutta muutamia muutoksia on nähtävissä, kun katsomme 1980-luvun määritelmää:

Selkokieltä on tietoisesti ja suunnitelmallisesti muutettu niin rakenteellisesti kuin sisällöllisesti helpommaksi ymmärtää. Tyypillisesti selkokielinen viesti tai taideteos suunnataan jollekin rajatulle väestörybmälle, jonka vastaanottokyvyssä tiedetä̈n olevan puutteita. Rajala \& Virtanen (1986, s. 31)

Vertailtaessa tätä nykyiseen huomataan, että nykyisin selkokieli suhteutetaan yleiskieleen. Selkokielen ja yleiskielen suhde oli ollut pitkään mukana selkokielen kehittäjien pohdinnoissa (esim. Rajala, 1990, s. 9), ja sen lisäämistä varsinaiseen määritelmään ehdotti esimerkiksi Vinni (1998, s. 48). Selkokeskus sisällytti suhteen osaksi määritelmää vuosituhannen vaihteessa (Virtanen, 2002). Suhteen näkyminen määritelmässä saa pohjaa kohderyhmälle suuntaamisen ajatuksesta, mutta on huomioitava, että tietyissä konteksteissa ja tilanteissa kielimuotojen erot voivat jäädä melko pieniksi. Myös esimerkiksi Saksassa erotetaan helppo yleiskieli (Einfache Sprache) varsinaisesta selkokielestä (Leichte Sprache) (Leskelä, 2019a, s. 92-94).

Aikaisemmassa selkokielen määritelmässä kielimuodon ominaisuuksista puhutaan kahdella tasolla nykyisen kolmen sijaan. Selkokielen ohjeistukset ovat laajentuneet ja tarkentuneet aikojen kuluessa, ja tämä näkyy määritelmässä. Myös viittaus kohderyhmiin on muuttunut: nykyisin määritelmä ottaa joustavammin huomioon erilaiset pysyvät tai tilapäiset syyt selkokielen tarpeelle.

Selkokielen määrittelyn lisäksi Selkokeskus on halunnut selvittää, miten paljon Suomessa on tarvetta selkokielelle. Ensimmäiseksi varsinaiseksi selkokielen tarpeen arvioksi Suomessa voidaan laskea kartoitus Selkokieli ja sen tarve eri vammaisryhmissä (Virtanen, 1986). Nimensä mukaisesti arviosta puuttui monia sellaisia ihmisryhmiä, jotka nykyisin lasketaan selkokielen tarvitsijajoukkoon, ja muutenkin arvio ryhmistä oli varovainen. Kokonaismääräksi kartoituksessa saatiin 50 000-70 000 ihmistä. Jo tässä kartoituksessa selkokielen tarvetta ajatellaan kokonaismäärän lisäksi myös ikäkausittain. Prosentuaalisesti arviossa annetaan tarpeeksi 4-6\% lasten ja nuorten keskuudessa ja aikuisväestössä 2-3 \% (Virtanen, 1986, s. 20-24).

Seuraavassa selvityksessä (Virtanen, 1989 , s. 6-7) selkokielen tarpeeksi arvioitiin 100 000-200 000 ihmistä, kun mukaan otettiin jo mm. vanhukset ja siirtolaiset, vaikka tarkkaa tutkimusta näiden kohderyhmien selkokielen tarpeesta ei ollutkaan saatavilla. Myöhemmin on tehty useita tarvearvioita, ja selkokielen 
tarvitsijoiden määrä on arvioiden mukaan kasvussa. Kohderyhmien määrällisten tietojen lisäksi arviota laadittaessa nojataan nykyisin myös mm. lukutaitotutkimuksiin, joita Suomessa tehdään OECD:n aloitteesta niin kouluikäisillä kuin aikuisväestöllä (Leskelä, 2019a, s. 104-106).

\subsection{Toiminnan ensiaskeleet}

Suomessa äänekkäimmin selkokielen puolta pidettiin aluksi kehitysvammahuollon piirissä, vaikka oli selvää, että helpompi kieli voi auttaa myös muita ihmisryhmiä. Selkokieltä edistivätkin alkuun vahvimmin kehitysvamma-alan järjestöt Kehitysvammaliitto, Kehitysvammaisten tukiliitto sekä ruotsinkielinen Förbundet De Utvecklingsstördas Väl. Selkokielen kehittämisestä järjestösektorilla on seurannut kiinteät suhteet selkokielen tarvitsijaryhmiin, varsinkin kehitysvammaisiin lukijoihin (Virtanen, 2006).

Suomen ensimmäinen selkolehti, aikakauslehti Leija, näki päivänvalon vuonna 1983 Kehitysvammaisten tukiliiton julkaisemana. Lehdelle otettiin mallia Ruotsin Steget-lehdestä (Virtanen, 2006). Vuonna 1984 puolestaan sai alkunsa nykyinen Selkokielen neuvottelukunta, kun sosiaali- ja terveysjärjestöjen selkotyöryhmä perustettiin. Työryhmän ajatus on ollut alusta asti koota yhteen selkokielen kehittämisestä ja käytöstä kiinnostuneita tahoja sekä vaikuttaa näin selkokielen asemaan ja kehitykseen Suomessa (Virtanen, 1986, s. 9).

Selkokielisen uutislehden puolesta käytiin myös keskustelua - aina eduskuntaa myöten. Vuonna 1990 helmikuussa alkoi ilmestyä joka toinen viikko Selkouutiset-sanomalehti (vuodesta 2012 Selkosanomat nimellä) sekä sen sisarlehti LL-Bladet. Lehteä on alusta asti julkaisut Kehitysvammaliitto Raha-automaattiyhdistyksen (nyk. Veikkaus) tuella (Virtanen, 2006).
Kaksi vuotta myöhemmin, vuonna 1992 , myös Yleisradio aloitti selkolähetykset radiossa. Uutislähetyksen aloituspäätökseen varmasti vaikutti selkokielen saama huomio, mutta varsinaiset syyt aloittaa selkokielinen uutislähetys nojaavat pikemminkin historiaan ja politiikkaan. Sepän (2006) mukaan päätökseen vaikutti kasvava kysyntä, mutta ei suinkaan Suomessa. Kyseessä olivat toisen ja kolmannen polven amerikansuomalaiset, jotka halusivat vielä pitää yhteyttä sukunsa kotimaahan ja vahvistaa omaa vanhempiensa tai isovanhempiensa kielen osaamista. Samoihin aikoihin Suomi päätti myös kohdella paluumuuttajina inkerinsuomalaisia, jotka kaipasivat nyt uutisia Suomesta helpolla suomen kielellä. Yleisradiossa päätettiin parantaa ulkosuomalaisten palvelua tarjoamalla kerran viikossa 25 minuutin mittainen selkokielinen katsaus.

Kehitysvammaliitto oli mukana selkokirjallisuuden kehittämisessä heti kielimuodon rantauduttua Suomeen. 1970-luvulla perustetun selkokirjallisuuden työryhmän toiminnan tuloksena Orivedellä järjestettiin 1981 seminaari, jossa kartoitettiin selkokirjallisuuden tilannetta, selkiytettiin termejä ja pohdittiin selkokirjallisuuden kehittämiseen tähtääviä toimenpiteitä. Alussa selkokirjallisuudeksi laskettiin paljon ns. helppolukuista kirjallisuutta selkokielen ja selkokirjallisuuden määritelmän tarkentuessa muutamien seuraavien vuosien kuluessa (Rajala, 2006).

Vuonna 1990 selkokirjallisuuden tukemiseen jaettiin ensimmäisen kerran määräraha, 50000 markkaa - tämäkin sinnikkään ja pitkäjänteisen vaikuttamistyön ja eduskuntakeskustelun jälkeen (Peltomaa, 2006). Selkokirjallisuuden valtiontuen myötä vakiintui myös selkokirjojen tunnus (nuoli). Alun perin sitä käytti Kirjastopalvelu selkokirjoissaan, mutta opetusministeriön tuen alettua tunnus otettiin käyttöön kaikissa selkokirjoissa (Virtanen, 2006). 
1980-luvulla oli julkaistu joitakin selkokirjoja, mutta käytännössä vasta 1990-luvulla tukijärjestelmän myötä selkokirjallisuus lähti kunnolla kasvuun. Ensimmäinen mukautus suomenkielisestä kirjasta tehtiin heti vuosikymmenen alussa Pertti Rajalan mukauttaessa A. Paasilinnan teoksen Isoisää etsimässä vuonna 1990 (Virtanen, 2006).

Selkokirjallisuus sai alkuaikoinaan kahtalaisen vastaanoton: Selkokielen mahdollisuutta välittää hyvää kirjallisuutta kyseenalaistettiin. Lisäksi epäiltiin selkokirjallisuutta lukutaitoa tai sen kehitystä huonontavaksi (esim. Helakisa, 1980). Toisaalta joukko kirjailijoita myös innostui ajatuksesta ja suhtautui selkokieleen ja sen tuomaan saavutettavuuteen positiivisesti (Leskelä \& Kulkki-Nieminen, 2015, s. 134136; Virtanen, 2006). Nykyisin nähdään, että selkokirjallisuus voi pikemminkin madaltaa kynnystä lukea ja toimia monille ryhmille kannustavana polkuna lukemisen maailmaan kohti yleiskieltä ja sen sujuvaa lukemista (Leskelä, 2019a, s. 274).

Selkotoiminnan vakiintumisesta myös muualla Euroopassa kertoo kansainvälisten ohjeistusten laatiminen. Näitä ohjeita kehittivät sekä YK:n alainen kirjastojärjestö IFLA (1997) sekä kehitysvammaisten ja heidän omaistensa etujärjestö European Association of Inclusion International (ILSHM European Association, 1998). Molemmista ohjeistuksista on julkaistu suomennos teoksessa Teksti, joka rakastaa lukijaansa (2000), ja sittemmin nämä järjestöt ovat myös päivittäneet ohjeistuksiaan (IFLA, 2010; Inclusion Europe, 2009).

Selkokeskus on tuottanut omia teoriakirjoja ja oppaita selkoilmaisusta sekä ollut mukana julkaisemassa artikkelikokoelmia, joissa on käsitelty selkokieltä eri näkökulmista. Nykyisin Selkokeskus kehittää selkokieltä ja toimii yhteistyössä erilaisten tutkimusorganisaatioiden kanssa, jotta tutkimusta selkokielestä saataisiin lisää. Selkokeskus on myös aktiivisesti mukana kansainvälisessä selkotoiminnassa sekä toimii läheisessä yhteistyössä Suomen ruotsinkielisen selkokielen edistäjän LL-Centerin kanssa (Leskelä, 2019a, s. 110-114).

\subsection{Selkokielen tutkimus}

Selkokielen tarve ja oikeutus on pitkään ollut yhteiskunnassa laajasti ymmärrettyä, mutta varsinkin alkuinnostuksen jälkeen siihen on kielimuotona suhtauduttu myös kriittisesti ja epäillen (Leskelä \& Kulkki-Nieminen, 2015, s. 135-136). Yleisten epäilysten lisäksi 1990-luvulla kritiikkiä sai osakseen esimerkiksi luettavuuskaavojen suhde kirjoitusohjeisiin, joita julkaistiin selkokirjoittajille.

Viestinnäntutkimuksessa luettavuuskaavoja annettiin tarkistamaan tekstin vaikeustasoa, luettavuutta ja ymmärrettävyyttä (Wiio, 1968; Wiio, 1974, s. 193-195). Leskelän (2019a s. 86-88) mukaan vaikeusasteen arvioinnin lisäksi näiden kaavojen perusteella Selkokeskus myös muodosti periaatteita ja ohjeita, joiden avulla selkokirjoittaja tuottaisi hyvää selkokieltä.

Tunnetuimpia luettavuuskaavoja Suomessa lienevät Wiion (esim. 1974, s.194-195) luettavuuskaavat, vaikka samanlaista tutkimusta on monista eri maista ja kielistä. Tässä esitellään yksi Wiion kaavoista, jolla on yhtymäkohtia varsinkin selkokielen alkuaikojen ohjeistukseen:

$$
\begin{aligned}
\mathbf{L T}= & \mathbf{0 , 3 3 P S}+\mathbf{7 M S}-\mathbf{0 , 6 8} \text { jossa } \\
\mathrm{LT}= & \text { luokkataso peruskoulun luokkina } \\
\mathrm{PS}= & \text { Pitkät sanat }(4 \text { tai enemmän tavuja }) \\
& 100 \text { sanaa kohden. Sanat perus- } \\
& \text { muodoissaan. } \\
\mathrm{MS}= & \text { Määräsuhde eli (adjektiivit }+ \\
& \text { adverbit }) /(\text { substantiivit }+ \text { verbit })
\end{aligned}
$$


Wiion (1974, s. 186; 1974, s. 193) mukaan tekstin vaikeus riippuu yleistäen yli neljän tavun pituisten sanojen määrästä (perusmuodossaan), vierasperäisten ja vieraiden sanojen määrästä, adjektiivien ja adverbien määrän suhteesta verbeihin ja substantiiveihin sekä pitkien virkkeiden määrästä (yli 14-15 sanaa). Kaavaan on näistä otettu pitkät sanat, sekä määräsuhde. Kaavan arvot lasketaan sadan sanan näytteestä. Tuloksena kaavasta saadaan koululuokka-aste, jolle teksti on sopivan vaikea tai helppo.

Esimerkiksi Turunen (1994) ja Laurinen (1994) vertasivat alkuvuosien selkokirjoittamisen ohjeita luettavuuskaavoihin ja kritisoivat niiden käyttöä selkokielen kirjoitusohjeiden pohjana. Laurisen (1994) mukaan selkokielen normeiksi Wiion kaavoista ovat muodostuneet vaatimus käyttää lyhyitä lauseita, välttää vaikeita lauserakenteita, suosia verbejä ja substantiiveja, vähentää adjektiiveja ja adverbeja sekä ottaa huomioon kohderyhmän kielelliset taidot ja tausta. Laurisen mukaan luettavuuskaavoista johdetuilla selkokirjoittamisen ohjeilla voidaan kirjoittaa hyvin monen tasoista kieltä. Hän nostaakin esille myös sidosteisuuden asteen teksteissä luettavuutta parantavana tekijänä. Laurinen osoittaa, että mukaan otetut 1980-luvun selkotekstit sisältävät vähemmän sidosteisuutta kuin verrokkitekstit.

Turunen (1994) jakaa selkokielen ohjeet tekstin makro- ja mikrotason ohjeisiin ja huomauttaa, että viittaukset makrotasoon ovat vähäisiä. Hän korostaa sanojen abstraktiotason sekä sanojen muodostamien määriteketjujen merkitystä tekstin vaikeutta arvioitaessa merkitysluokkajaon sijaan, ja tämä käsitys on vallalla myös nykyisissä ohjeistuksissa (Leskelä, 2019a, s. 130-131). On kuitenkin huomioitava, että luettavuuskaavojen lisäksi selkokielen periaatteet ovat perustuneet kansainvälisiin selkokielen ohjeisiin (IFLA, 2010; ILSHM European Association, 1998), joista löytyy monia samoja ohjeita, esimerkiksi kohdat lyhyet lauseet ja helpot rakenteet, ja niitä voidaan myös perustella muistin ja lukemisen tutkimuksilla (Leskelä, 2019a, s. 89).

Tutkimusten ja kritiikin pohjalta Selkokeskus kehitti ohjeita voimakkaasti tekstitason suuntaan (Virtanen, 2014 [2009]), s. 112118), ja ohjeistuksissa alettiin kiinnittää huomiota esimerkiksi tekstin koheesioon ja informaatiorakenteeseen (Sainio \& Rajala, 2002). Esimerkiksi Ruotsissa vielä nykyäänkin osa selkokielen määrittelystä perustuu LIX-luettavuuskaavaan (Läsbarhetsindex, 2019), eikä maassa ole yhtenäistä käsitystä selkokielestä tai esimerkiksi vastaavaa tunnusjärjestelmää kuin Suomessa (Leskelä, 2019a, s. 87-89).

Myöhemmin selkotekstejä on analysoitu tekstilajien näkökulmasta (Kulkki-Nieminen \& Leskelä, 2012). Myös selkokielen ohjeita on eriytetty koskemaan osin vain tiettyjä tekstilajeja, jotta ohjeet palvelisivat paremmin kirjoittajan tarpeita kirjoitusprosessin aikana ja tuottaisivat lukijalle parempia tekstejä (Leskelä, 2019a, s. 124-125; Leskelä \& KulkkiNieminen, 2015).

Koska selkokieltä on kehitetty yhdessä kohderyhmien kanssa ja heitä varten, myös tutkimustieto liittyen lukukokemuksiin ja luetun ymmärtämiseen on ollut arvokasta. Vinnin (1998 s. 70-71) mukaan kehitysvammaisten aikuisten selkokielisten ja yleiskielisten tekstien ymmärtäminen eroaa selvästi toisistaan. Tutkimuksessa koehenkilöt lukivat tekstikatkelmia, ja lukemista arvioitiin vapaan palautuksen menetelmällä sekä varmistuskysymyksillä. Koehenkilöillä yleiskielisten tekstien ymmärtämisen taso (asteikolla tunnistava, toistava, päättelevä, arvioiva) jää selkeästi useimmin vain tunnistavalle tasolle ja esimerkiksi arvioivaa ymmärtämistä ei esiinny ollenkaan. Selkoteksteissä tunnistavan luennan sijaan koehenkilöt päätyivät jo toistavaan sekä melko usein päättelevään luentaan, ja muutama heistä jopa arvioivaan luentaan. 
Vinnin tutkimus oli selkokielelle merkittävä, koska se oli ensimmäinen selkokieltä käsittelevä väitöskirja Suomessa. Sen olemassaolo ja myös tulokset antoivat uskoa selkokielen kehittäjille sekä toivoa uusista tutkimuksista.

2000-luvulla Numminen (2006) käsittelee selkokieltä ja lukemista muistintutkimuksen valossa. Selkokielen käyttäjäryhmien kannalta muistin ja lukemisen yhteys on sikäli merkittävä, että erilaisia muistin ongelmia löytyy Nummisen mukaan monien selkokielen käyttäjäryhmien taustalta. Ongelmat työmuistissa vaikeuttavat esimerkiksi pitkien lauserakenteiden prosessointia ja ymmärtämistä. Ongelmat korostuvat, jos mekaaninen lukutaito on heikko ja lukeminen hidasta. Pitkäkestoisen muistin ongelmat tai puutteet vaikeuttavat puolestaan tekstin sanaston, käsitteiden välisten yhteyksien sekä viittausten ymmärtämistä. Numminen arvelee selkokielen olevan yksi tehokkaimmista kielellisesti työmuistia keventävistä apuvälineistä ja uskoo sen auttavan myös luetun ymmärtämistä ja oppimista. Tulokset viittaavat siihen, että vaikka kohderyhmien tarpeet ja vaikeat asiat kielessä voivat olla erilaisia, selkokieli voi hyödyttää kaikkia ryhmiä.

Merkittävää kielitieteellistä tutkimusta Suomessa selkokielen osalta on tehnyt Kulkki-Nieminen, joka on osallistunut Selkokeskuksen kanssa selkokielen teoreettiseen kehittelyyn (esim. Kulkki-Nieminen, 2002) ja tutkinut mm. selkouutisen piirteitä (2010). Kulkki-Niemisen (2010, s. 180-181) mukaan esimerkiksi teemanosan yksinkertaistaminen on selkotekstissä yleistä, ja se on tekstuaalinen keino muuttaa tekstiä helpommaksi. Lisäksi tutkimuksessa (2010, s. 39) todentuu, että selkokielessä pyritään välttämään liian pitkiä lausekkeisiin sisältyviä määriteketjuja: helppolukuinen lauserakenne edellyttää, että lauseen päajäsenet (predikaattiverbi ja subjekti) ovat suhteellisen helposti hahmotettavissa (ks. myös Virtanen, 2014 [2009], s. 98-100).
Lisäksi Kulkki-Niemisen (2010, s. 130) mukaan merkityksenantoa viedään mukautustyössä havainnollisemmalle tasolle. KulkkiNiemisen ja Leskelän (2012) mukaan tämä näkyy sananvalinnassa, lausekerakenteessa ja tekstin rakenteessa. Substantiivisuus vähenee, kun käsitteitä puretaan ja käytetään havainnollisempia verbejä. Selkotekstissä informaatiorakenne ja teemankulku saadaan selkeämmäksi esimerkiksi karsimalla yksityiskohtia.

Edellä esitettyjen tutkimusten lisäksi esimerkiksi Leskelä (2012b) ja Lindholm (2012) ovat tehneet keskustelunanalyyttistä tutkimusta selkokielestä vuorovaikutustilanteissa. Selkokieltä on tutkittu myös opinnäytteissä kielitieteissä (esim. Arle, 2018; Jokipii, 2017; Laine, 2013; Nummi, 2013; Uotila, 2012) ja kirjallisuustieteissä (esim. Sipilä, 1995; Taneli, 2005).

Selkokielen tutkimus on etenemässä Suomessa. Suomessa uusimpia kiinnostuksen kohteita ovat olleet esimerkiksi selkokielen ja alkusanateorian (ks. esim. Vanhatalo \& Tissari, 2017) yhteydet sekä näiden anti molempien tutkimukseen ja kehittämiseen. Suomessa alkusanojen ja selkokielen yhteyttä ovat tutkineet esimerkiksi Vanhatalo ja Lindholm (2020). Keväällä 2018 Helsingin yliopistossa perustettiin Klaara-verkosto selkokielen tutkijoille (ks. www.klaaranetwork.fi). Tätä katsausta viimeisteltäessä Helsingissä on jo järjestetty ensimmäinen kansainvälinen selkokieltä käsittelevä konferenssi Klaara 2019, jossa esillä oli kahden päivän ajan selkokielen tutkimusta yli kymmenestä maasta. Klaarakonferenssi saa jatkoa vuonna 2020 Sveitsissä.

Suomen lisäksi selkokielen tutkimus ja kehitys on ottanut kansainvälisesti suuria harppauksia 2010-luvulla. Esimerkiksi Saksassa on perustettu Selkokielen tutkimuskeskus vuonna 2014 Hildesheimin yliopistoon ja monet viranomaistoimijat tuottavat materiaaleja selkokielellä (Leskelä, 2019a, s. 91-92; ks. lisää Bredel \& Maaß, 2015). 


\section{SELKOKIELEN SOVELLUKSIA}

Selkokeskus myöntää ilmaisen selkotunnuksen materiaaleille, jotka vastaavat selkokielen periaatteita. Nykyisin selkotunnuksen voivat saada esitteet ja oppaat, verkkosivut sekä videot. Selkokeskus myöntää selkotunnuksen

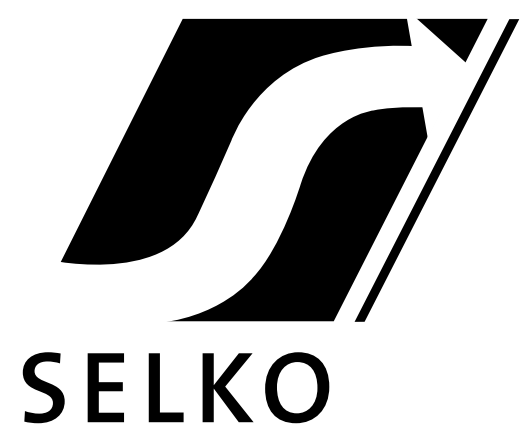

myös ruotsinkielisille aineistoille, mutta yhteistyössä LL-Centerin kanssa. Selkokirjoille tunnuksen myöntää Selkokeskuksen yhteydessä toimiva selkokirjatyöryhmä.

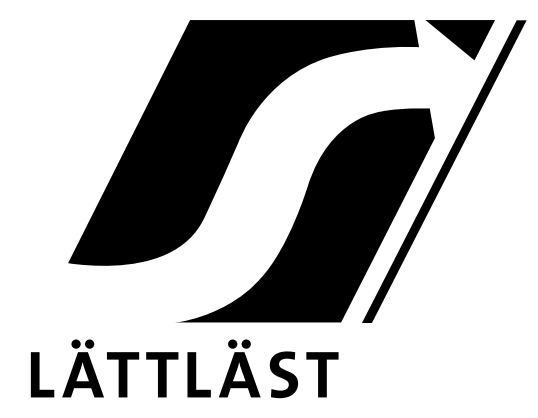

Selkokielisen julkaisun tunnistaa Selkokeskuksen myöntämästä tunnuksesta.

\subsection{Selkolehdet}

Suomessa ilmestyy kaksi selkolehteä: Uutislehti Selkosanomat sisarlehtensä LL-Bladetin kanssa sekä aikakauslehti Leija. Selkolehtien tilausmäärät liikkuvat tuhansissa. Puhuttaessa kaikkien selkolehtien levikistä on syytä huomioida, että lehtiä tilataan usein asuntoloihin, työ- ja toimintakeskuksiin ja esimerkiksi kirjastoihin. Näissä kaikissa samaa lehteä lukevat monet ihmiset ja niitä luetaan ryhmissä. Todellinen lukijamäärä on siis huomattavasti tilausmääriä suurempi. Tällä hetkellä myös kaikki selkolehdet ilmestyvät verkossa: esimerkiksi Selkosanomia lukee vuosittain arviolta noin 65000 ihmistä (Leskelä, 2019a, s. 267-268).

Nuorille ja aikuisille kehitysvammaisille suunnattu aikakauslehti Leija ilmestyy kuusi kertaa vuodessa. Leskelän (2019a, s. 272) mukaan Leijan tärkeimpiä tehtäviä on kehitysvammaisten osallistaminen lehden teke- miseen esimerkiksi juttujen, haastattelujen, runojen ja valokuvien kautta. Selkokielen kannalta lehti ottaa myös huomioon sisältöjen yksinkertaistamisen kielen pintatason lisäksi.

Selkokeskus julkaisee Selkosanomat ja $L L$ Bladet -lehtiä 20 kertaa vuodessa kahden viikon välein (paitsi kesä- ja joulutauoilla). Lehtien verkkosivuilla (www.selkosanomat.fi, www.ll-bladet.fi) julkaistaan myös painettujen lehtien välillä verkkouutisia. Ilmestymisaikataulu pakottaa ja toisaalta antaa mahdollisuuden taustoittaa uutisaiheita. Selkolehtien lukijoilla on tavallista huonommat medialukutaidot, joten lehden on erityisen tärkeää noudattaa hyvän journalismin periaatteita. Esimerkiksi erilaiset juttutyypit (uutinen, mielipidekirjoitus) pyritään erottamaan toisistaan selkeästi myös taitollisin ratkaisuin (Leskelä, 2019a, s. 267-268). Lisäksi Virtanen (2014 [2009], s. 157) korostaa selkoleh- 
dissä kuvien hankinnan huolellisuutta, jotta teksti, otsikot ja kuvat täydentävät toisiaan.

Kuten Leijalle, myös Selkosanomille on ollut tärkeää säilyttää kontakti lukijoihin ja kehittää lehteä myös yhdessä heidän kanssaan. Lehti on järjestänyt säännöllisesti lukijatapaamisia ja teettänyt pienimuotoisia lukijatutkimuksia, joissa on esimerkiksi arvioitu lehden kieltä ja sen vaativuutta sekä lehteä sisältönsä puolesta uutislehtenä (Leskelä, 2019a, s. 269-270). Lukijakyselyissä Selkosanomiin ja sen kieleen on oltu tyytyväisiä. Lehti on koettu ajankohtaiseksi ja itselle sopivaksi monissa eri selkokielen tarvitsijaryhmissä (Juusola, 2016, s. 5-9).

\subsection{Kirjallisuus}

Yksi merkittäviä ja vakiintuneita selkoilmaisun muotoja Suomessa on selkokielinen kirjallisuus. Kirjoja tehdään nykyisin noin 15-20 vuosittain, ja nimikkeinä ilmestyy sekä yleiskielisistä kirjoista tehtyjä versioita eli mukautuksia sekä ns. alkuperäiskäsikirjoituksia (Leskelä, 2019a, s. 274).

Suomessa on julkaistu yli 400 kirjaa selkokielellä. Varsinkin selkokirjallisuuden kahden ensimmäisen vuosikymmenen aikana voidaan sanoa, että iso osa julkaistuista kirjoista oli luonteeltaan jollakin tapaa sivistävää, kasvattavaa tai opettavaista: esimerkiksi suomalaisen kirjallisuuden klassikoita tai opettavaisia tarinoita arkielämästä.

Kevyempää kirjallisuutta on saatu enemmän oikeastaan vasta 2010-luvulla. Selkokirjojen laatuun on panostettu 2000-luvulla ja myös niiden ilmestymismäärät ovat kasvaneet. Nykyisin valtaosa ilmestyvästä kirjallisuudesta on kertomakirjallisuutta, josta noin puolet on alkuperäistekstejä ja puolet mukautuksia jo julkaistuista yleiskielisistä kirjoista. Mukana on erilaisia kirjoja klassikoista dekkareihin, fantasiaan sekä novelli- ja runokokoelmiin (Leskelä, 2019a, s. 276-277).
Selkokeskus on tehnyt vuosia työtä, että selkokirjallisuus tunnettaisiin paremmin ja että kohderyhmät saisivat tietoa julkaistuista selkokirjoista. Selkokeskus esimerkiksi julkaisee vuosittain esitteen selkokirjoista sekä osallistuu kirjamessuille (Leskelä, 2019a, s. 281). Selkokirjoja on tuotu esille viime vuosina myös selkokirjakummi-toiminnan kautta. Ideana on ollut saada tunnettujen suomalaisten kirjailijoiden kirjoja selkokielelle ja samalla myös näitä kirjailijoita edistämään selkokirjallisuutta. Selkokirjakummitoiminnan aloitti Anna-Leena Härkösen Häräntapppoase (mukautettu 2013), minkä jälkeen on mukautettu Reijo Mäen dekkari Pimeyden tango (2015), Eppu Nuotion Peiton paikka (2017) sekä Tuomas Kyrön Mielensäpahoittaja (2019) (Leskelä, 2019a, s. 277).

Selkokirjallisuuden elinehto tällä hetkellä on Opetus- ja kulttuuriministeriön Selkokeskukselle delegoima selkokirjallisuuden ja muun saavutettavan kirjallisuuden tuki. Tukea jaetaan kerran vuodessa kirjailijoille, kuvittajille, kustantajille ja koskettelukirjojen tekijöille. Päätökset tuista tehdään työryhmässä, johon Selkokeskus kutsuu kirjailijaliittojen, kirjastoseuran ja selkokielen neuvottelukunnan edustajia. Tukisummat eivät ole suuria, mutta niiden merkitys pienille kustantamoille ja tälle vähälevikkiselle kirjallisuudelle on suuri (Leskelä, 2019a, s. 274).

\subsection{Esitteet ja verkkojulkaisut}

Selkokeskus on vuosien varrella julkaissut yhteistyössä eri tahojen kanssa useita esitteitä ja tehnyt tiedotuskampanjoita. Ne ovat voineet olla osa viranomaistiedotusta (esimerkiksi Kelan etuusesitteet ja Oikeusministeriön vaaliesitteet) tai niillä on muuten haluttu jakaa kohderyhmille tietoa ja taitoja. Esitteissä aiheina ovat olleet myös mm. matkailu, rahankäyttö ja YK:n vammaissopimus (Virtanen, 2014 [2009], s. 161-163). 
Osa esitteistä on tuotettu kokonaan muualla, mutta niille on haettu ilmainen selkotunnus Selkokeskuksesta. Leskelän (2019a, s. 284-286) mukaan kansalaistaitoja tukevia materiaaleja pitäisi tuottaa järjestelmällisemmin kuin nykyään. Nykyisin materiaaleja julkaistaan painettuina esitteinä ja oppaina sekä verkkomateriaalina. Selkokeskus myöntää yhdessä Papunet-verkkopalvelun kanssa verkkosivuille selkotunnuksen, kun ne täyttävät asetetut kriteerit. Valittu julkaisumuoto riippuu kohderyhmästä; esimerkiksi nuorille suunnattuja materiaaleja tehdään nykyään useammin verkkoon. Verkkosivutekstien ja ladattavien materiaalien (esim. pdf-muoto) lisäksi viime vuosina on tehty myös videoita, joille on myönnetty selkotunnus.

Selkokielistä kansalaistietoutta on koottu esimerkiksi www.selko.fi-sivustolle. Hyviä esimerkkejä laajoista selkoaineistoista löytyy myös Satakunnan sairaanhoitopiirin verkkosivuilta (www.satasairaala.fi) ja Helsingin seutuportaalista (www.helsinginseutu.fi/sel$\underline{\text { ko). }}$. Kela on julkaissut pitkään etuusesitteensä selkokielellä, ja nyt Kela on näiden esitteiden pohjalta perustamassa selkokielistä kieliversiota sivuilleen.

\subsection{Ylen selkountiset}

Yle Uutiset selkosuomeksi -lähetykset ovat löytäneet hyvin yleisönsä, ja niitä käytetään monen eri kohderyhmän parissa. Nykyisin Yle lähettää viisiminuuttisen selkouutiset-lähetyksen radiossa joka päivä sekä TV-lähetyksinä arkisin. Lähetykset ovat kuunneltavissa ja katsottavissa Yle Uutiset selkosuomeksi -lähetyksen kotisivuilla ja YleAreenassa. Selkokielinen TV-lähetys on poikkeuksellinen maailmassa, eikä vastaavia ole Selkokeskuksen tiedoissa Ruotsia lukuun ottamatta. Yle Uutiset selkosuomeksi -lähetyksissä käsitellään samoja aiheita kuin Ylen muussa uutistuotannossa. Lähetykseen nos- tetaan myös nykyistä pääkohderyhmää eli maahanmuuttajataustaisia henkilöitä erityisesti kiinnostavia aiheita (Leskelä, 2019a, s. 270). Sepän (2006) mukaan päätös pääkohderyhmän vaihtamisesta ulkosuomalaisista maahanmuuttajataustaisiin henkilöihin tehtiin vuonna 2003 heidän edustaessa valtaosaa kuulijoista.

Yle Uutiset selkosuomeksi -lähetyksessä on kehitetty kuultuna ymmärrettävää selkokieltä pitkään ja huolellisesti. Varsinkin radiolähetyksessä kuulijat ovat kertakuuleman armoilla, joten selityksiin ja virkerakenteisiin on kiinnitetty erityistä huomiota. Lähetykset suunnataan kielen oppimisen ja opetuksen eurooppalaisen viitekehyksen taitotasolle A2-B1. Selkouutisten lähetys on myös pitkään kerännyt palautetta kohderyhmiltä sekä ottanut mukaan kieliharjoittelijoita journalistiseen työhön (Leskelä, 2019a, s. 270-271).

\section{TULEVAISUUS}

Selkokieli on Suomessa kasvanut, kehittynyt ja elänyt yhteiskunnan ja kohderyhmiensä tarpeiden mukana neljä vuosikymmentä. Itse asiassa etuliitteen selko- käyttöönottamisesta tuli syksyllä 2018 kuluneeksi tasan neljäkymmentä vuotta. Monet selkokielen asemaa ja selkojulkaisuja koskevat julkilausutut tavoitteet ovat toteutuneet vuosien varrella. Selkokielen - ja selkokielen käyttäjien - kannalta monessa kohtaa on siis onnistuttu ja viety asiaa ansiokkaasti eteenpäin.

Tutkimusta selkokielestä on toivottu selkokielen historian alusta asti. Tässä lyhyessä katsauksessa on nostettu vuosien varrelta tutkimuksia, jotka tuloksillaan ja olemassaolollaan ovat vaikuttaneet selkokielen kehitystyöhön. Tutkimusta on tehty erityispedagogiikan, muistintutkimuksen, neuropsykologian, kirjallisuustieteen ja kielitieteen aloilla. Jokainen tutkimus on itsessään voitto 
selkokielelle, sillä vain tieteellisen tutkimuksen kautta selkokieltä saadaan vietyä eteenpäin ja kehitettyä lukijoilleen entistä paremmin toimivaksi.

Jatkossa selkokieli kaipaa vielä lisää lingvististä tutkimusta, jotta saadaan paremmin määriteltyä, mitä on selkokieli. Tämän tutkimuksen lisäksi on erittäin tarpeellista tutkia selkokielen kohderyhmien tapaa ja kykyä käyttää kieltä ja erityisesti selkokieltä. Tutkimus ei toivottavasti rajoitu puhtaasti selkokieleen, vaan mukaan kaivataan lisää tutkimusta myös mm. selkokuvasta ja -ilmaisusta ylipäätään, silmänliike- ja vastaanottotutkimusta, vuorovaikutustutkimusta, vammaistutkimusta ja pedagogista tutkimusta. Yhtä lailla myös esimerkiksi logopedian ja puheterapian aloilla on paljon annettavaa selkoilmaisun tutkimukselle. Tutkijalle selkokieli on haastava ja antoisa kohde: Selkokieli linkittyy vahvasti reaalimaailmaan, ja paljon on jo saatu aikaan. Tilaa on kuitenkin vielä uusille oivalluksille ja tutkimushankkeille.

\section{SELKOKIELISET AINEISTOLÄHTEET}

Helsingin seutuportaali selkokielellä. Haettu 30.9.2019 osoitteesta www.helsinginseutu.fi/ hs/selkosivut-fi

Härkönen, A-L. (2013). Häräntappoase. selkomukautus. Johanna Kartio. Helsinki: Opike, Kehitysvammaliitto ry.

Mäki, R. (2015). Pimeyden tango. selkomukautus Ari Sainio. Helsinki: Opike, Kehitysvammaliitto ry.

Nuotio, E. (2017). Peiton paikka. selkomukautus Johanna Kartio. Helsinki: Opike, Kehitysvammaliitto ry.

Paasilinna, A. (1990) Isoisää etsimässä. selkomukautus Pertti Rajala. Helsinki: Kirjastopalvelu.

Selko.fi. Haettu 30.9.2019 osoitteesta www.selko.fi

Selkosanomat verkossa. Haettu 30.9.2019 osoitteesta www.selkosanomat.fi

Yle uutiset selkosuomeksi. Haettu 30.9.2019 osoitteesta www.yle.fi/selkouutiset

\section{LÄHTEET}

Arle, S. (2018). Hur används primord for att skriva lättläst? En undersökning av tre återberättade romaner. Pro gradu -tutkielma. Helsinki: Helsingin yliopisto.

Bredel, U. \& Maaß, C. (2015). Leichte Sprache. Theoretische Grundlagen, Orientierung, für die Praxis. Berlin: Dudenverlag.

(EU) $2016 / 2102=$ Euroopan parlamentin ja neuvoston direktiivi julkisen sektorin elinten verkkosivustojen ja mobiilisovellusten saavutettavuudesta. Haettu 26.8.2019 osoitteesta https://eur-lex.europa.eu/legal-content/FI/ TXT/?uri=CELEX\%3A32016L2102

Helakisa, K. (1980). Lukikirjainlukijainkirje - eli reunamerkintöjä ja kysymysmerkkejä selko- ja helppokirjoja lukiessa. Lastenkulttuurijulkaisu Tyyris tyllerö 3/80 (s. 16-17). Espoo: Cultura.

Hallintolaki $=6.6 .2003 / 434$ Hallintolaki. Haettu 28.8.2918 osoitteesta https://www.finlex.fi/fi/ laki/ajantasa/2003/20030434

IFLA (1997). Guidelines for easy-to-read materials. Teoksessa B. I. Tronbacke (toim.), IFLA professional reports, no. 54. The Hague: International Federation of Library Associations and Institutions.

IFLA (2010). Guidelines for easy-to-read materials. International Federation of Library Associations and Institutions IFLA Professional Reports 120. Haettu 28.8.2019 osoitteesta www.ifla.org/files/hq/publications/professional-report/120.pdf

ILSHM European Association (1998). Tee se helpoksi. Eurooppalainen opas selkokielisen informaation tuottamiseksi kehitysvammaisille ihmisille - kirjoittajille, toimittajille, tiedon tuottajille, kääntäjille ja muille kiinnostuneille. Haettu 28.8.2019 osoitteesta http://jkorpela. fi/helpoksi.html

Inclusion Europe (2009). Make your information accessible! European standards to make information easy to read and to understand. Haettu 28.8.2019 osoitteesta http://easy-to-read.eu/ wp-content/uploads/2014/12/EN Information for all.pdf

Jokipii, P-M. (2017). Keskustelijoiden roolit kehitysvammaisten henkilöiden selkoryhmissä. Pro Gradu -tutkielma. Vaasa: Vaasan yliopisto. 
Juusola, M. (2016). Selkosanomien lukijakysely. Haettu 28.8.2019 osoitteesta https:// selkokeskus.fi/wordpress/wp-content/uploads/2017/08/Selkosanomien_lukijakysely 2016.pdf

Klaara-network $=$ selkokielen tutkijaverkoston kotisivu. Haettu 6.4.2019 osoitteesta www. klaaranetwork.fi

Kulkki-Nieminen, A. (2002). Selkokielen ja yleiskielen eroista. Teoksessa H. Virtanen (toim.), Selko-opas, (s. 33-45). Helsinki: Kehitysvammaliitto ry.

Kulkki-Nieminen, A. (2010). Selkoistettu uutinen: Lingvistinen analyysi selkotekstin erityispiirteistä. Tampere: Tampere University Press.

Kulkki-Nieminen, A. \& Leskelä, L. (2012). Selkoistaminen ja tekstilajit. Teoksessa V. Heikkinen, E. Voutilainen, P. Lauerma, U. Tiililä \& M. Lounela (toim.), Genreanalyysi: tekstilajitutkimuksen käytäntö̈. (s. 545-574). Kotimaisten kielten keskuksen verkkojulkaisuja 29. Helsinki: Kotimaisten kielten keskus. Haettu 28.8.2018 osoitteesta http://kaino.kotus.fi/www/verkkojulkaisut/julk29/Genreanalyysi.pdf

Laine, A. (2013). Selkoa säädösteksteistä. Suomen vammaispoliittisen ohjelman ja selkoversion lingvistinen analyysi. Pro gradu -tutkielma. Helsinki: Helsingin yliopisto.

Laurinen, L. (1994). Selko- vai sekokieltä - selkokielisten tekstien ymmärrettävyydestä. Teoksessa A. Sainio (toim.), Selkoa selkokielestä, (s. 33-61). Helsinki: Kirjastopalvelu.

Leskelä, L. (2012a). Selkokielisen vuorovaikutuksen ohjeet. Teoksessa L. Leskelä \& C. Lindholm (toim.), Haavoittuva keskustelu: Keskustelunanalyyttisiä tutkimuksia kielellisesti epäsymmetrisestä vuorovaikutuksesta, (s. 279-298). Helsinki: Kehitysvammaliitto ry.

Leskelä, L. (2012b). Ymmärrysvaikeuksien käsittelyä kehitysvammaisten henkilöiden ja heidän ohjaajiensa keskusteluissa. Teoksessa L. Leskelä \& C.Lindholm (toim.), Haavoittuva keskustelu: Keskustelunanalyyttisiä tutkimuksia kielellisesti epäsymmetrisestä vuorovaikutuksesta, (s. 184234). Helsinki: Kehitysvammaliitto ry.

Leskelä, L. (2019a). Selkokieli. Saavutettavan kielen opas. Helsinki: Kehitysvammaliitto ry.

Leskelä, L. (2019b). Helppoa vai vaativampaa selkokieltä - selkokielen mittaaminen ja vaikeustasot. Pube ja kieli, 39, 367-393.
Leskelä, L. \& Kulkki-Nieminen, A. (2015). Selkokirjoittajan tekstilajit. Helsinki. Kehitysvammaliitto ry, Oppimateriaalikeskus Opike.

Leskelä, L. \& Lindholm, C. (2012a). Näkökulmia kielellisesti epäsymmetriseen vuorovaikutukseen. Teoksessa L. Leskelä \& C. Lindholm (toim.), Haavoittuva keskustelu: Keskustelunanalyyttisiä tutkimuksia kielellisesti epäsymmetrisestä vuorovaikutuksesta, (s. 12-31). Helsinki: Kehitysvammaliitto ry.

Leskelä, L. \& Lindholm, C. (2012b). Lukijalle. Teoksessa L. Leskelä \& C. Lindholm (toim.), Haavoittuva keskustelu: Keskustelunanalyyttisiä tutkimuksia kielellisesti epäsymmetrisestä vuorovaikutuksesta, (s. 7-11). Helsinki: Kehitysvammaliitto ry.

Lindholm, C. (2012) Vuorovaikutuksen haasteita ja mahdollisuuksia - tapaustutkimus muistisairaiden päivätoiminnasta. Teoksessa L. Leskelä \& C. Lindholm (toim.), Haavoittuva keskustelu: Keskustelunanalyyttisiä tutkimuksia kielellisesti epäsymmetrisestä vuorovaikutuksesta, (s. 5798). Helsinki: Kehitysvammaliitto ry.

LL-Center (2019) = LL-Centerin kotisivut. Haettu 30.9.2019 osoitteesta www.ll-center.fi Lukukeskus (2017). 10 faktaa lukemisesta. Haettu 28.8.2019 osoitteesta http://lukukeskus.fi/wpcontent/uploads//2017/11/10-faktaa-pdf-fedit.pdf

Läsbarhetsindex (2019) = Lix-luettavuuskaava. Haettu 30.9.2019 osoitteesta www.lix.se

Malin, A. (2006). Suomessakin on heikkoja lukijoita. Teoksessa L. Leskelä \& H. Virtanen (toim.), Toisin sanoen. Selkokielen teoriaa ja käytäntöä, (s. 15-31). Helsinki: Kehitysvammaliitto ry.

Nummi, C. (2013). Sanastotason selkeys selkokielisessä tekstissä. Vertaileva tutkimus Selkosanomien ja Helsingin Sanomien uutisartikkeleista. Pro Gradu -tutkielma. Vaasa: Vaasan yliopisto. Numminen, H. (2006). Muisti ja lukeminen. Teoksessa L. Leskelä \& H. Virtanen (toim.), Toisin sanoen. Selkokielen teoriaa ja käytäntö̈̈, (s. 32-36). Helsinki: Kehitysvammaliitto ry.

Papunet (2019) = Papunet verkkopalvelun saavutettavuussivut. Haettu 30.9.2019 osoitteesta www.papunet.net/saavutettavuus 
Peltomaa, M. (2006). Selkokirjatyöryhmän taival. Teoksessa L. Leskelä \& H. Virtanen (toim.), Toisin sanoen. Selkokielen teoriaa ja käytäntö̈̈, (s. 119-130). Helsinki: Kehitysvammaliitto ry.

PIAAC $=$ OECD's Programme for the International Assessment of Adult Competencies. Haettu 28.8.2019 osoitteesta https://www.oecd.org/ skills/piaac/.

PISA = OECD's Programme for International Student Assessment. Haettu 28.8.2019 osoitteesta http://www.oecd.org/pisa/.

Rajala, P. (1990). Selkokirjoittajan opas. Helsinki: Kirjastopalvelu.

Rajala, P. (2006). Muistikuvia selkokirjoistani. Teoksessa L. Leskelä \& H. Virtanen (toim.), Toisin sanoen. Selkokielen teoriaa ja käytäntö̈̈, (s. 104-118). Helsinki: Kehitysvammaliitto ry.

Rajala, P. \& Virtanen, H. (1986) Selkokieli: Miten sanoma perille? Helsinki: Kirjastopalvelu.

Teksti, joka rakastaa lukijaansa (2000). Sainio, A. (toim.). Helsinki: BTJ Kirjastopalvelu

Sainio, A. \& Rajala, P. (2002). Ohjeita selkokirjoittajille. Teoksessa H. Virtanen (toim.), Selkoopas, (s. 23-32). Helsinki: Kehitysvammaliitto.

Sainio, A. (2006). Oikeus kelpo tarinoihin, selkokirjojen mukauttamisesta. Teoksessa L. Leskelä \& H. Virtanen (toim.), Toisin sanoen. Selkokielen teoriaa ja käytäntöä, (s. 131-154). Helsinki: Kehitysvammaliitto ry.

Selkokeskus $(2019 \mathrm{a})=$ Selkokeskuksen kotisivut. Haettu 30.9.2019 osoitteesta www.selkokeskus.fi.

Selkokeskus (2019b). Selkokielen toimenpideohjelma. Selkokielen edistäminen Suomessa vuosina 2019-2022. Helsinki: Kehitysvammaliitto ry. Haettu 28.8.2019 osoitteesta https:// selkokeskus.fi/wp-content/uploads/2019/02/ Selkokielen-toimenpideohjelma-2019.pdf

Selkokeskus (2019c). Selkokielen tarvearvio 2019. Helsinki: Kehitysvammaliitto ry. Haettu 28.8.2019 osoitteesta https://selkokeskus. fi/wp-content/uploads/2019/02/Tarvearvio-2019.pdf

Seppä, P. (2006). YLE Radio Finlandin selkouutiset. Teoksessa L. Leskelä \& H. Virtainen (toim.), Toisin sanoen. Selkokielen teoriaa ja käytäntöä (s. 168-197). Helsinki: Kehitysvammaliitto.

Sipilä, L. (1995). Selkokieli ja kaunokirjallisuus. Pro gradu -tutkielma. Tampereen yliopiston taideaineiden laitos.
Tieteen termipankki (2019). Kielitiede: yleiskieli.

(Haettu 28.8.2019 osoitteesta: https://tieteentermipankki.fi/wiki/Kielitiede:yleiskieli.)

Taneli, M. (2005). Klassikkokirjan mukauttaminen selkokielelle. Tapausesimerkkinä Nummisuutarit: komedia viidessä näytöksessä. Pro gradu -tutkielma. Tampereen yliopiston taideaineiden laitos.

Turunen. M. (1994). Selkokielen määrittelystä. Teoksessa A. Sainio (toim.), Selkoa selkokielestä, (s. 21-32). Helsinki: Kirjastopalvelu.

Uotila, E. (2012). Selkokieltä esitteillä. Kelan selkoja yleiskielisten esitteiden tekstuaalinen analyysi. Pro gradu -tutkielma. Helsinki: Helsingin yliopisto.

Vanhatalo, U. \& Lindholm, C. (2020). Prevalence of NSM primes in easy-to-read and standard Finnish: Findings from newspaper text corpora. Teoksessa L. Sadow, B. Peeters, \& K. Mullan (toim.), Studies in ethnopragmatics, cultural semantics, and intercultural communication. Vol. 3. Minimal English (and Beyond), (s. 213-234). Springer.

Vanhatalo, U. \& Tissari, H. (2017). Esittelyssä alkusanakieli. Virittäjä, 121, 244-263.

Vehmas, S. (2005). Vammaisuus. Johdatus historiaan, teoriaan ja etiikkaan. Helsinki: Gaudeamus.

Vinni, I. (1998). Tekstistä selkoa: kehitysvammaisten aikuisten selko-ja yleiskielisten tekstien ymmärtäminen. Valtakunnallisen tutkimus- ja kokeiluyksikön julkaisuja 76. Helsinki: Kehitysvammaliitto ry.

Virtanen, H. (1986). Selkokieli ja sen tarve eri vammaisryhmissä. Helsinki: Sosiaaliturvan keskusliitto.

Virtanen, H. (1989). Selkosovellutusten tarve, Helsinki: Sosiaalihallitus.

Virtanen, H. (2006). Selkokirjoista selkokieleen, tapahtui vuosina 1981-1990. Teoksessa L. Leskelä \& H. Virtainen (toim.), Toisin sanoen. Selkokielen teoriaa ja käytäntöä, (s. 87-103). Helsinki: Kehitysvammaliitto ry.

Virtanen, H. (2014 [2009]). Selkokielen käsikirja. 4. uudistettu laitos. Helsinki. Kehitysvammaliitto ry.

Virtanen. H (2002). Selkokielen määritelmä, tarve ja käyttäjäryhmät. Teoksessa Hannu Virtanen (toim.), Selko-opas, (s. 7-21). Helsinki: Kehitysvammaliitto ry. 
Wiio, O. A. (1968). Readability, Comprehension and Readership. Tampereen yliopisto. Acta Universitatis Tamperensis A: 22.

Wiio, O. A. (1974). Ymmärretäänkö sanomasi. Viestintä - tiedonvälitys. 5. uudistettu painos. Helsinki: Weilin \& Göös.

Yhdenvertaisuuslaki $=30.12 .2014 / 1325$ Yhdenvertaisuuslaki. Haettu 28.8.2019 osoitteesta https://www.finlex.fi/fi/laki/ajanta$\underline{\mathrm{sa} / 2014 / 20141325}$.

YK-liitto (2015). YK:n yleissopimus vammaisten henkilöiden oikeuksista. Haettu 28.8.2019 osoitteesta https://www.ykliitto.fi/sites/www. ykliitto.fi/files/vammaisten oikeudet 2016 net.pdf. 


\section{EASY LANGUAGE IN FINLAND - HISTORY AND DEVELOPMENT OF EASY FINNISH}

Eliisa Uotila, University of Helsinki

This review article focuses on the development of Easy Finnish and presents easy materials as well as Finnish research on easy language. Easy language was developed in Finland in the 1980s, to serve the needs of people with intellectual and developmental disabilities, although soon other groups became equally important (e. g. immigrants, and people with memory disorders). Developing easy language within target groups has been a driving force in Finland, but developers have also relied on the theoretical background from research; for example, special education, communications and memory research. By definition, Easy Finnish is a form of Finnish in which standard language has been adapted in terms of content, vocabulary and structure. These aspects of language, together with elements of typography, layout and pictures, form the guidelines for easy materials. Easy language has also long been used in spoken interaction. Its aim is to prevent language-based exclusion. For several decades, news, literature and various informative materials (e. g. on voting, Kela benefits) have been published in easy language in Finland.

Keywords: accessibility, easy-to-read language, easy-to-read literature 